\title{
A new combination is made in Bothriocline (Compositae: Vernonieae), based on Erlangea fruticosa, an apparently rare plant from Guinea and Sierra Leone
}

\section{J. Nicholas Hind ${ }^{1}$}

Summary. Work towards the Compositae records for a checklist of the flora of Guinea (Conakry) provided some contentious records. Although 'Bothriocline fruticosa (C.D.Adams) Lisowski' appeared in Lisowski's posthumous Flora account of the Asteraceae (= Compositae), no such combination has ever been validly published. Based on Erlangea fruticosa, material of this taxon has been curated (following the most recent revision of the East African species) for the last thirty years under the $\mathrm{A}-\mathrm{Z}$ species of Bothriocline. It is clear that this material belongs in Bothriocline; the formal transfer is now made.

Key Words. Asteraceae, checklist, curation, Endangered.

\section{Introduction}

Under the project 'Important Plant Areas in Guinea,' supported by the Darwin Initiative of the Department of the Environment Food and Rural Affairs (DEFRA), UK government (Project Ref. 23-002), I have made an attempt at checking and editing the checklist of Compositae for Guinea. This was based in part on a preliminary listing provided by George Gosline using Lisowski's posthumous Flora account (Lisowski 2009), together with determinations of subsequent collections in the country from Kew's surveys between 2006 and 2018. A number of issues were thrown up as a result.

Stanislas Lisowski (11 February 1924 - 2 May 2002) submitted the manuscript for the first part of the Flore de la République de Guinée in 2000. A protracted period of editing saw this volume published in early 2009 (Lisowski 2009). The Flora format precluded publication references to any names (accepted or synonyms) thus any novelties are invalidly published (following the present Code - Turland et al. 2018) if not previously validated in the literature. Within the Compositae account, one such name is that of 'Bothriocline fruticosa (C.D.Adams) Lisowski', based on Erlangea fruticosa C.D.Adams (1964). Based on the holotype and three paratypes (the holotype and one paratype are in K), the taxon occurs in Guinea and Sierra Leone. Gerald Pope, then Krukoff Curator of African Botany and the editor of Flora Zambesiaca, curated the material under Bothriocline Oliv. \& Benth., where it has been for at least the last 25 years. The name was included within a typed index, based upon Jeffrey (1988) — the entry appearing 'fruticosa ... A - Z'. Kew's Bothriocline Region 10A genus cover contains material of this taxon, together with B. schimperi Oliv. \&
Hiern ex Benth. (also in the $\mathrm{A}-\mathrm{Z}$ species) and indet. material.

The material of Erlangea fruticosa possesses many of the characters found in Bothriocline (cf. Wild \& Pope 1977a, b), in that the leaves are alternate, relatively short-, but distinctly- petiolate, the flagelliform stem hairs are densely adpressed-sericeous, each with stack of several short, septate, amber-coloured thick-walled cells and a longfiliform, uniseriate, eglandular apical cell; the leaf hairs are similar to the stem hairs but considerably less dense and erect. In the flowering structures, the phyllaries possess laciniate margins and a sparsely to moderately dense glandular-punctate midrib area, the glands reddish in dried material; the corolla lobes are glabrous apically, and abaxially sparsely glandular-punctate. The achenes are fawn-coloured with broad, rounded ribs with eglandular sinuses, and the apical cup (within which the base of the corolla sits) has pappus setae arising from inside the rim - Pope's 'Cypsela type 3' — but lacking any trichomes in the sinuses (Pope 1983). The pappus setae are elongated spindle-shaped, their base reddish, but are coarsely barbellate throughout, and the apex long-acute to attenuate. Erlangea fruticosa is therefore clearly a Bothriocline. The following validating new combination is consequently made.

\section{New combination}

Bothriocline fruticosa (C.D.Adams) Lisowski ex D.J.N.Hind, comb. nov.

http:/ /www.ipni.org/urn:lsid:ipni.org:names:77194749-1

Accepted for publication 28 February 2019. Published online 10 April 2019

1 Herbarium, Royal Botanic Gardens, Kew, Richmond, TW9 3AE, UK. e-mail: n.hind@kew.org 
Erlangea fruticosa C.D.Adams, J. W. African Sci. Assoc. 8 (2): 134 (1963)[Aug. 1964]. Type: 'GuineA. — Mt. Benna, Kindia, flower and fruit November 1937, Jaques-Felix 2123 (Holotypus K); ...' Holotype: K (000874616).

'Bothriocline fruticosa (C.D.Adams) Lisowski', Fl. Repub. Guinée, pt. 1: 80 (2009), nom. inval. (i.e. in not citing the place of publication of the basionym it was contrary to Art. 41.5 of the Code - Turland et al. 2018 - and lacked any indication that it was a new combination).

DISTRIBUTION. Guinea, Sierra Leone.

CONSERVATION STATUS. The draft IUCN conservation assessment (to be reviewed) for this taxon is Endangered, since only three threat-based locations are known and the "area of occupancy" is only $12 \mathrm{~km}^{2}$ (Cheek pers. comm. Jan. 2019).

\section{Acknowledgements}

The author would like to thank two anonymous referees for their comments in improving the original draft of this short paper.

Open Access This article is distributed under the terms of the Creative Commons Attribution 4.0 International License (http://creativecommons.org/ licenses/by/4.0/), which permits unrestricted use, distribution, and reproduction in any medium, provided you give appropriate credit to the original author(s) and the source, provide a link to the Creative Commons license, and indicate if changes were made.

\section{References}

Adams, C. D. (1963) [Aug. 1964]. New records of flowering plants in West Africa. VI.-Compositae (Conclusion). J. W. African Sci. Assoc. 8 (2): $134-140$.

Jeffrey, C. (1988). The Vernonieae in East Tropical Africa. Notes on Compositae: V. Kew Bull. 43 (2): 195 - 277.

$\nmid$ Lisowski, S. (2009). Flore (Angiospermes) de la République de Guinée. Première partie (texte). Scripta Bot. Belgica 41: [i] - vii, 1 - 517. [Asteraceae: 72 - 96.]

Pope, G. V. (1983). Cypselas and trichomes as a source of taxonomic characters in the erlangeoid genera. Kirkia 12(2): 203 - 231.

Turland, N. J., Wiersama, J. H., Barrie, F. R., Greuter, W., Hawksworth, D. L., Herendeen, P. S., Knapp, S., Kusber, W.-H., Li, D.-Z., Marhold, K., May, T. W., McNeill, J., Monro, A. M., Prado, J., Price, M. J. \& Smith, G. F. (eds) (2018). International Code of Nomenclature for algae, fungi, and plants (Shenzhen Code) adopted by the Nineteenth International Botanical Congress, Shenzhen, China, July 2017. Regnum Veg. 159. Koeltz Botanical Books, Glashütten. DOI https://doi.org/10.12705/Code.2018

Wild, H. \& Pope, G. V. (1977a). New and interesting Compositae from south-central Africa. 3. Kirkia 10(2): $309-338$.

\& _ (1977b). The Compositae of the Flora Zambesiaca area 7 - Vernonieae (excluding Vernonia Schreb.). Kirkia 10(2): 339 - 384 [keys to all genera and useful generic descriptions].

\section{Publisher's Note}

Springer Nature remains neutral with regard to jurisdictional claims in published maps and institutional affiliations. 